\title{
3 Tesla Magnetic resonance imaging and multiplanar reconstruction of the brain and its associated structures in pig*
}

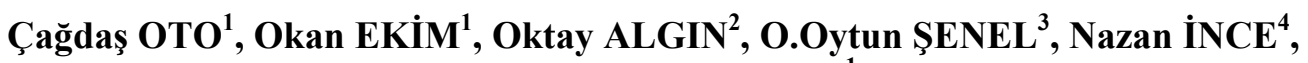 \\ R. Merih HAZIROGLU ${ }^{1}$
}

\begin{abstract}
${ }^{1}$ Ankara University, Faculty of Veterinary Medicine, Department of Anatomy - Ankara, ${ }^{2}$ Ankara Atatürk Education and Research Hospital, Clinic of Radiology - Ankara, ${ }^{3}$ Ankara University, Faculty of Veterinary Medicine, Department of Surgery - Ankara, ${ }^{4}$ İstanbul University, Faculty of Veterinary Medicine, Department of Anatomy - İstanbul, Turkey.
\end{abstract}

Summary: Determination of 3 Tesla MR imaging appearance of the brain and associated structures was the aim of this study. T1 and T2-weighted (W) and 3D reformatted images obtained from 6 adult pigs were used to define the cranioencephalic structures and anatomic details in three planes. Relevant structures were identified and labeled at each level. Especially T1W images scanned with three-dimensional inversion recovery multiplanar reconstruction (3D-IR-MPR) sequence provided excellent visualization for the inner structures of head and brain.

Key words: Anatomy, brain, magnetic resonance imaging, pig

\section{Domuzda beyin ve ilişkili yapıların 3 Tesla manyetik rezonans ile görüntülenmesi ve multiplanar rekonstruksiyonu}

Özet: Bu çalışmada, domuzda beyin ve ilişkili yapıların 3 Tesla MR ile görüntülenmesi amaçlandı. Çalışmada 6 adet yetişkin domuza ait T1 ve T2-ağırlıklı imajlar ile 3 boyutlu rekonstrukte edilmiş görüntüler kullanıldı. Cranioencephalic yapılar ve anatomik detaylar üç planda ve her kesit üzerinde tanımlanarak işaretlendi. Özellikle 3D-IR-MPR sekansı ile alınan T1-ağırlıklı görüntüler, baş ve beyine ait derin yapıların mükemmel düzeyde görüntülenmesini sağladı.

Anahtar sözcükler: Anatomi, beyin, domuz, manyetik rezonans görüntüleme

\section{Introduction}

Magnetic resonance imaging (MRI) is a non-invasive technique performing non-ionizing radiation which can differentiate between the types of distinct tissues due to differences in structure and water content (20). It is commonly employed for the imaging of the body, especially the central nervous system, because of its ability to obtain with high soft tissue contrast, high field strength and decreasingly scanning time (19). Therefore, MRI has an importance in diagnosis and treatment of the pathologies such as tumours, hydrocephalus, haematoma, demyelinating diseases and vascular malformations of the head in veterinary practise (22). It also has been used commonly in imaging for anatomy education and researches $(3,13,14,26)$.

Swine are increasingly used in biomedical researches and are being replaced with the other mammalian species as an animal model. They have become accepted as a general surgical model (21). However, its use in the neurologic researches has been relatively uncommon due to the thickness of the neurocranium and massive nature of the facial bones (21), and the swine have been developed as a model for skull base surgery $(6,10)$, for cranial bone graft materials (18) and stroke models (5, $12,23,24)$. On account of that, understanding the sectional anatomy of the normal brain and related structures and MR imaging features of the tissues are quite important in the diagnosis and treatment of clinical diseases, experimental studies and also imaging anatomy of the head (4). In our literature review, it was noticed that the anatomical based MRI studies about the pig brain wasn't satisfactory $(8,17,25)$. The purpose of the study was to define imaging features of the normal structures of the head and to provide an overview of MR imaging anatomy of the brain and surrounding structures in the pig. Designation of the most convenient sequence that enables to delineate the anatomic details was also the aim of this study. By this way it helps the clinicians to determine the head pathologies and the researchers for biomedical investigations as a reference.

\footnotetext{
A part of this study was presented as a poster presentation at $6^{\text {th }}$ National Congress of Veterinary Anatomy, 16-19 September 2010, Afyon-Turkey.
} 


\section{Materials and Methods}

Six adult pigs, weighted 70-110 kg, were used for this investigation. The study protocol was approved by the Animal Ethics Committee of Ankara University. The pigs were sedated with Xylazine $\mathrm{HCl}(1,5 \mathrm{mg} / \mathrm{kg}$, i.m.), followed by intramuscular injection of Ketamine $\mathrm{HCl}$ $(12,5 \mathrm{mg} / \mathrm{kg})$ for the induction of general anesthesia. The cranial structures of the pigs were imaged by 3 Tesla MR (Trio, Siemens, Erlangen, Germany) using standard birdcage head coil. Whole brain and associated structures were scanned with three-dimensional (3D), T1-weighted (W) gradient echo inversion recovery (IR) multiplanar reconstruction (MPR) sequence in sagittal plane with isotropic voxels for reformation. Technical parameters were standardized as following; TE: $2.5 \mathrm{~ms}$; TR: $1900 \mathrm{~ms}$; TI: $900 \mathrm{~ms}$; acquisition time; $4.17 \mathrm{~min}$; slice thickness: 1 $\mathrm{mm}$; field of view: $400 \times 400 \mathrm{~mm}$; matrix: $246 * 246$; number of slices: 176. Two-dimensional (2D) T2W sequence was also performed in the sagittal, frontal and transversal planes. The protocols were TE: $93 \mathrm{~ms}$; TR: $6000 \mathrm{~ms}$; time of acquisition: $1.18 \mathrm{~min}$; slice of thickness: $3 \mathrm{~mm}$; field of view: $279 \times 279 \mathrm{~mm}$; matrix: $640 * 640$; number of slice: 20 . The total scanning time of the sequences were approximately $15 \mathrm{~min}$. After scanning procedure, data collected from T1W - IR - MPR sequence were reconstructed with $1 \mathrm{~mm}$ slice thickness and $1 \mathrm{~mm}$ interslice gap in sagittal, frontal and transversal directions using Leonardo workstation software (Siemens Medical Solutions, Erlangen, Germany). Anatomical lines and their alignments were identified on mid-sagittal plane and orthogonal directions were orientated to external acoustic meatus in frontal and transversal planes.

Definition of the anatomical structures were based on the atlases and textbooks regarding pig anatomy and MRI $(2,7,11,16)$. Nomina Anatomica Veterinaria was used for the nomenclature (9).

\section{Results}

T1 and T2W MRI were performed in detail for whole brain and associated structures in three planes. Clinically relevant anatomic formations were identified and labeled in the corresponding images. The intracranial length, height and the width of the brain were measured with software as $90.2 \mathrm{~mm}, 56.3 \mathrm{~mm}, 59,3 \mathrm{~mm}$ in average respectively.

In $\mathrm{T} 1 \mathrm{~W}$ images, it was observed that the anatomical details were superior due to the high geometric resolution. The grey matter was more hypointense when compared with the white matter (fig 1, 2, 3, 4). Depending upon the high resolution and signal differences beside the brain ventricles and meninx, the inner brain structures such as olfactory bulb, caudate nuclei, corpus callosum, optic chiasm, thalamus, pituitary gland, pineal gland, mesencephalic tectum and cerebellum were well imaged (fig 1, 2, 3, 4, 5, 6). Cerebrospinal fluid (CSF) (fig 2) and blood (fig 3) were completely hypointense similar to the negligible signal intensity of the air in cranial sinuses (fig $1,5,6)$ and observed in black color. The cortical part of the

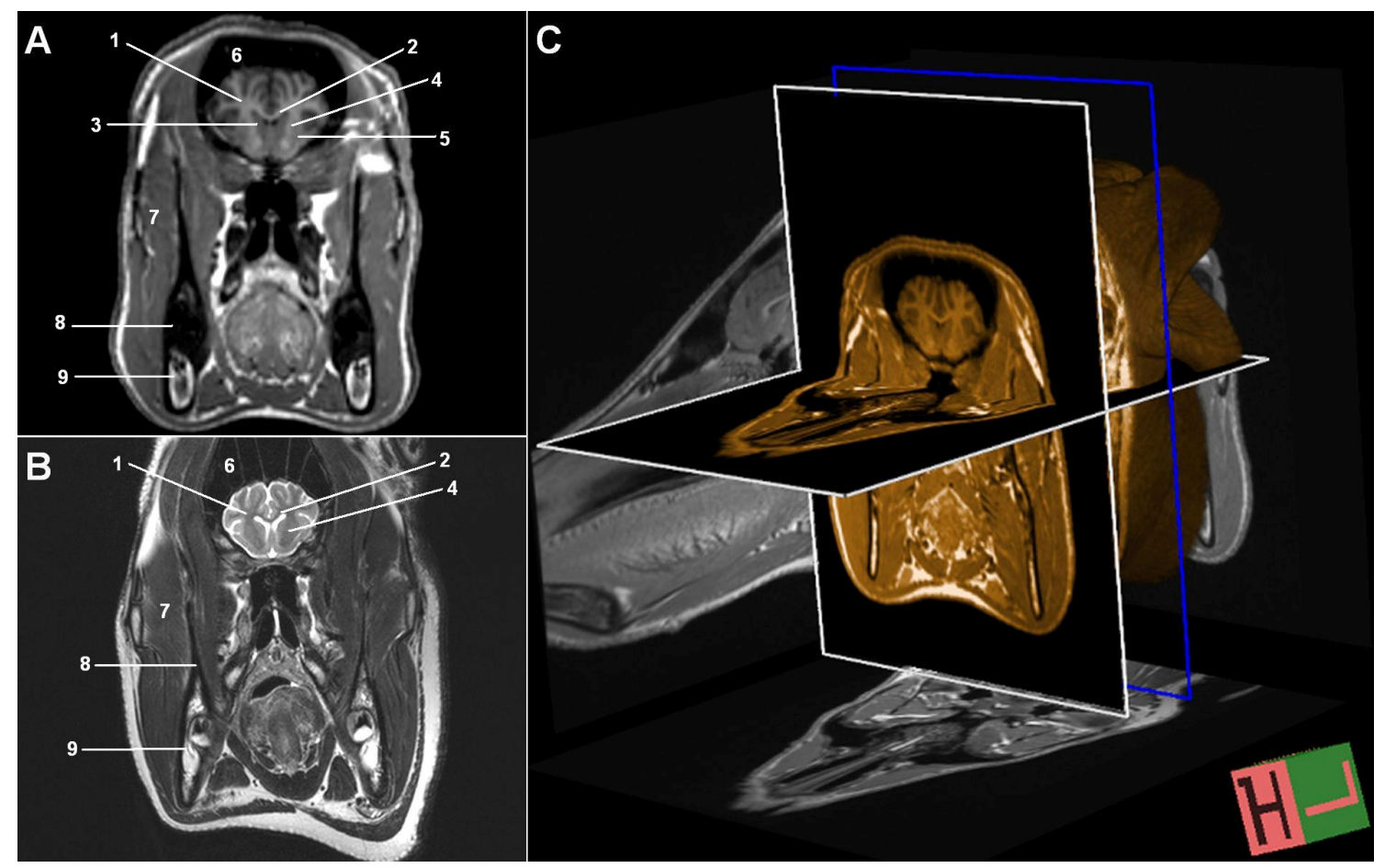

Figure 1. MR images of the brain at the level of caudate nuclei in transversal plane. A-) T1W, B- T2W, C-) T1W, 3D-IR-MPR volumetric images. 1 ; centrum semiovale, 2; corpus callosum, 3; nucleus caudatus, 4; capsula interna, 5; nucleus lentiformis, 6; sinus frontalis, $7 ; \mathrm{m}$. masseter, 8 ; mandibula (cortex), 9; mandibula (medulla).

Şekil 1. Transversal düzlemde, nucleus caudatus düzeyinde, beynin MR görüntüleri, A-) T1-ağırlıklı, B-) T2-ağırlıklı, C- T1ağırlıkl1, 3D-IR-MPR volumetrik görüntüler. 

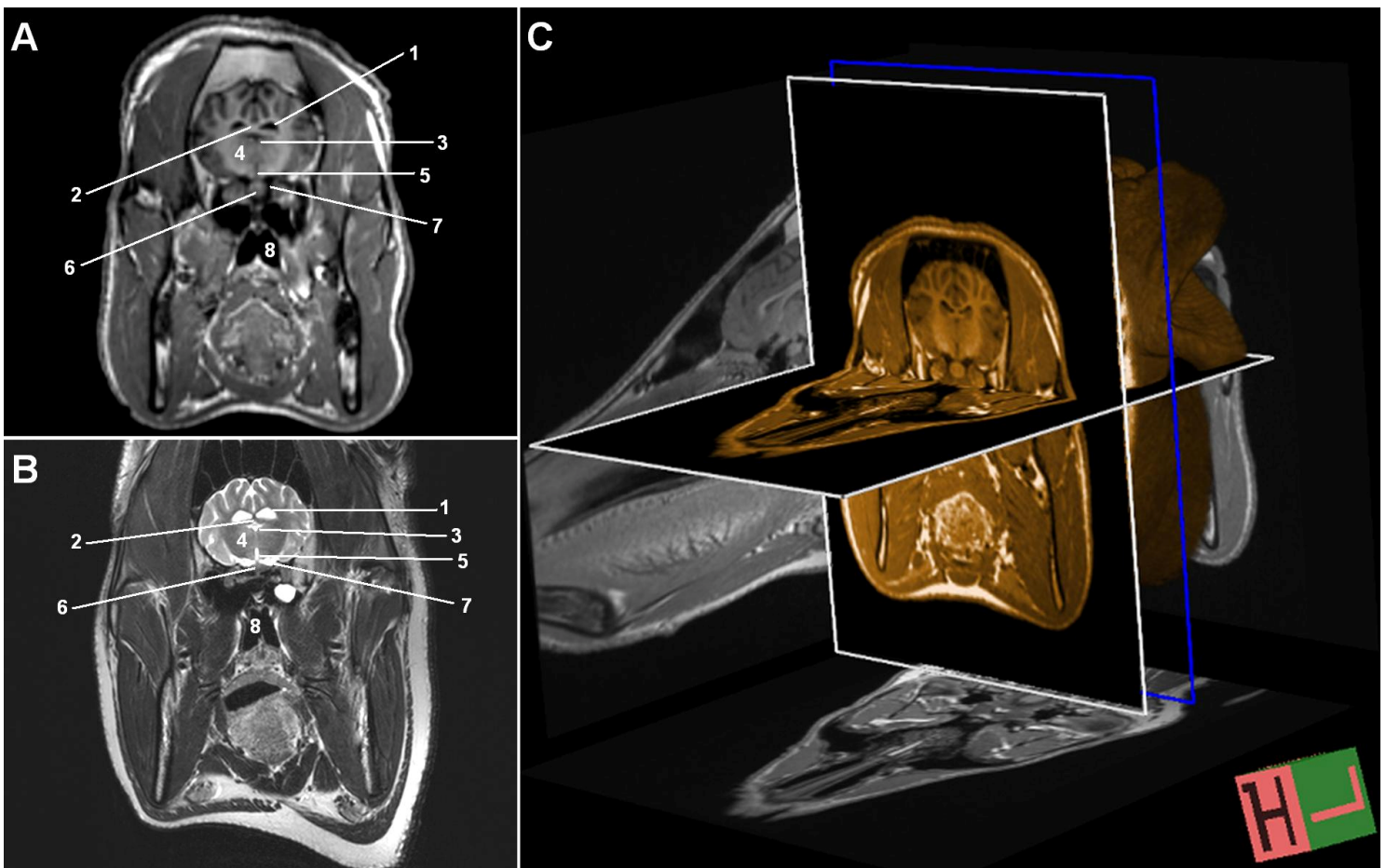

Figure 2. MR images of the brain at the level of hypophysis in transversal plane. A-) T1W, B- T2W, C-) T1W, 3D-IR-MPR volumetric images. 1; ventriculus lateralis, 2; septum pellucidum, 3; ventriculus tertius, 4; thalamus, 5; infundibulum, 6; hypophysis, 7; sinus cavernosus, 8; nasopharynx.

Şekil 2. Transversal düzlemde, hypophysis düzeyinde, beynin MR görüntüleri, A-) T1-ağırlıklı, B-) T2-ağırlıklı, C- T1-ağırlıklı, 3DIR-MPR volumetrik görüntüler.
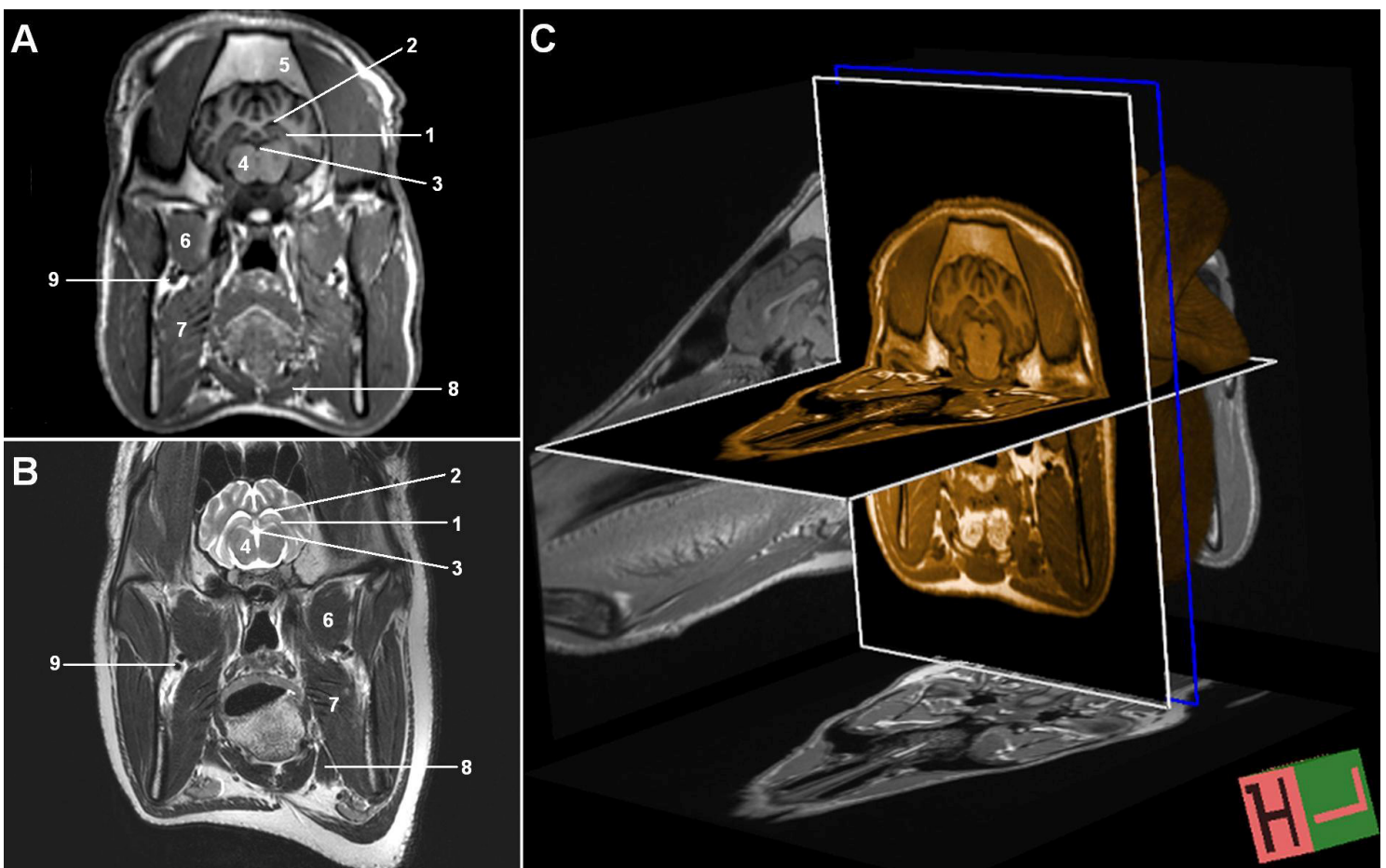

Figure 3. MR images of the brain at the level of hippocampus in transversal plane. A-) T1W, B- T2W, C-) T1W, 3D-IR-MPR volumetric images. 1; hippocampus, 2; ventriculus lateralis, 3; ventriculus tertius, 4; thalamus, 5; os frontale, 6; m. pterygoideus lateralis, $7 ; \mathrm{m}$. pterygoideus medialis, $8 ; \mathrm{m}$. digastricus, 9 ; a. et v. maxillaris.

Şekil 3. Transversal düzlemde, hippocampus düzeyinde, beynin MR görüntüleri, A-) T1-ağırlıklı, B-) T2-ağırlıklı, C- T1-ağırlıkl1, 3D-IR-MPR volumetrik görüntüler. 

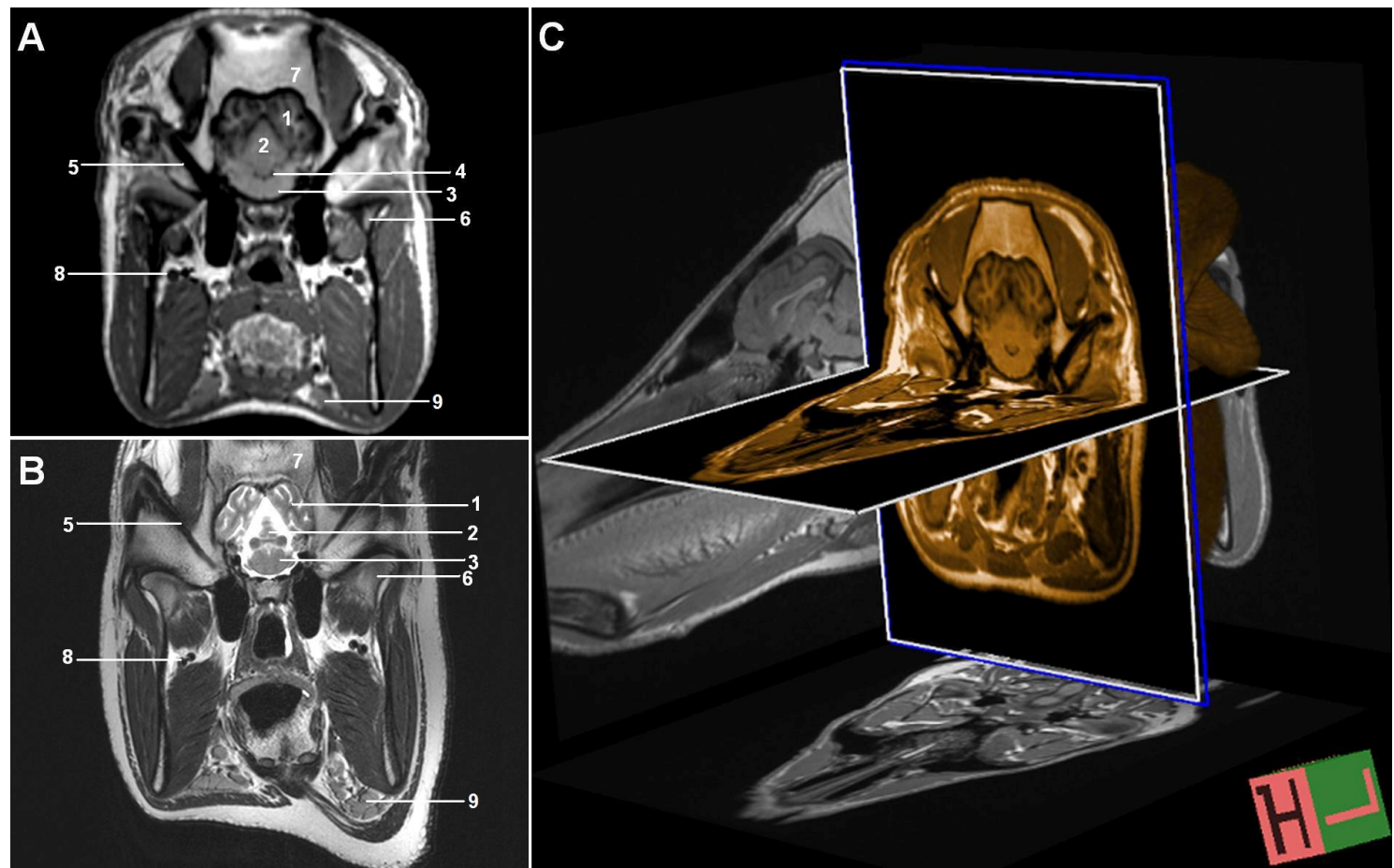

Figure 4. MR images of the brain at the level of pons in transversal plane. A-) T1W, B- T2W, C-) T1W, 3D-IR-MPR volumetric images. 1; cerebrum, 2; cerebellum, 3; pons, 4; ventriculus quartus, 5; meatus acusticus externus, 6; mandibula (proc.condylaris), 7; os frontale, 8; a. et v. maxillaries, 9; gl.parotis.

Şekil 4. Transversal düzlemde, pons düzeyinde, beyinin MR görüntüleri, A-) T1-ağırlıklı, B-) T2-ağırlıklı, C- T1-ağırlıklı, 3D-IRMPR volumetrik görüntüler.
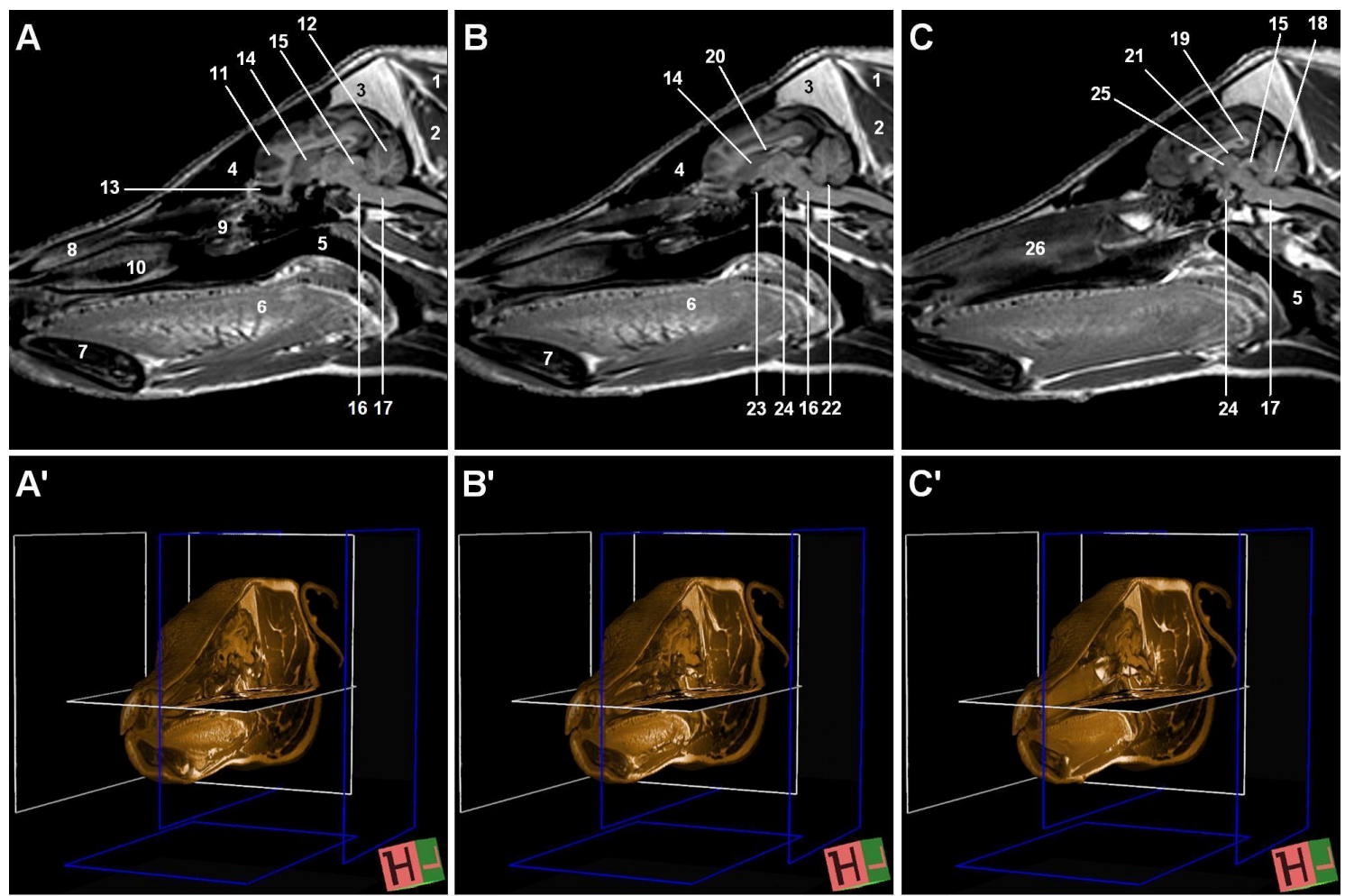

B'



Figure 5. MR images of the brain at three levels in sagittal plane. A-) T1W, B-) T1W, 3D-IR-MPR volumetric images. 1; m. semispinalis, 2; m. rectus capitis, 3; os frontale, 4;sinus frontalis, 5; pharynx, 6; lingua, 7; mandibula, 8; concha nasalis dorsalis, 9; concha nasalis media, 10; concha nasalis ventralis, 11; cerebrum, 12; cerebellum, 13; bulbus olfactorius, 14; nucleus caudatus, 15; tectum mesencephali, 16; pons, 17; medulla oblongata, 18; arbor vitae cerebelli, 19; corpus callosum, 20; ventriculus lateralis, 21; ventriculus tertius, 22; ventriculus quartus, 23; chiasma opticum, 24; hypophysis, 25; adhesio interthalamica, 26; cartilago septi nasi Şekil 5. Sagittal düzlemde, üç düzeyde, beynin MR görüntüleri, A-) T1-ağırlıklı, B-) T1-ağırlıklı, 3D-IR-MPR volumetrik görüntüler. 

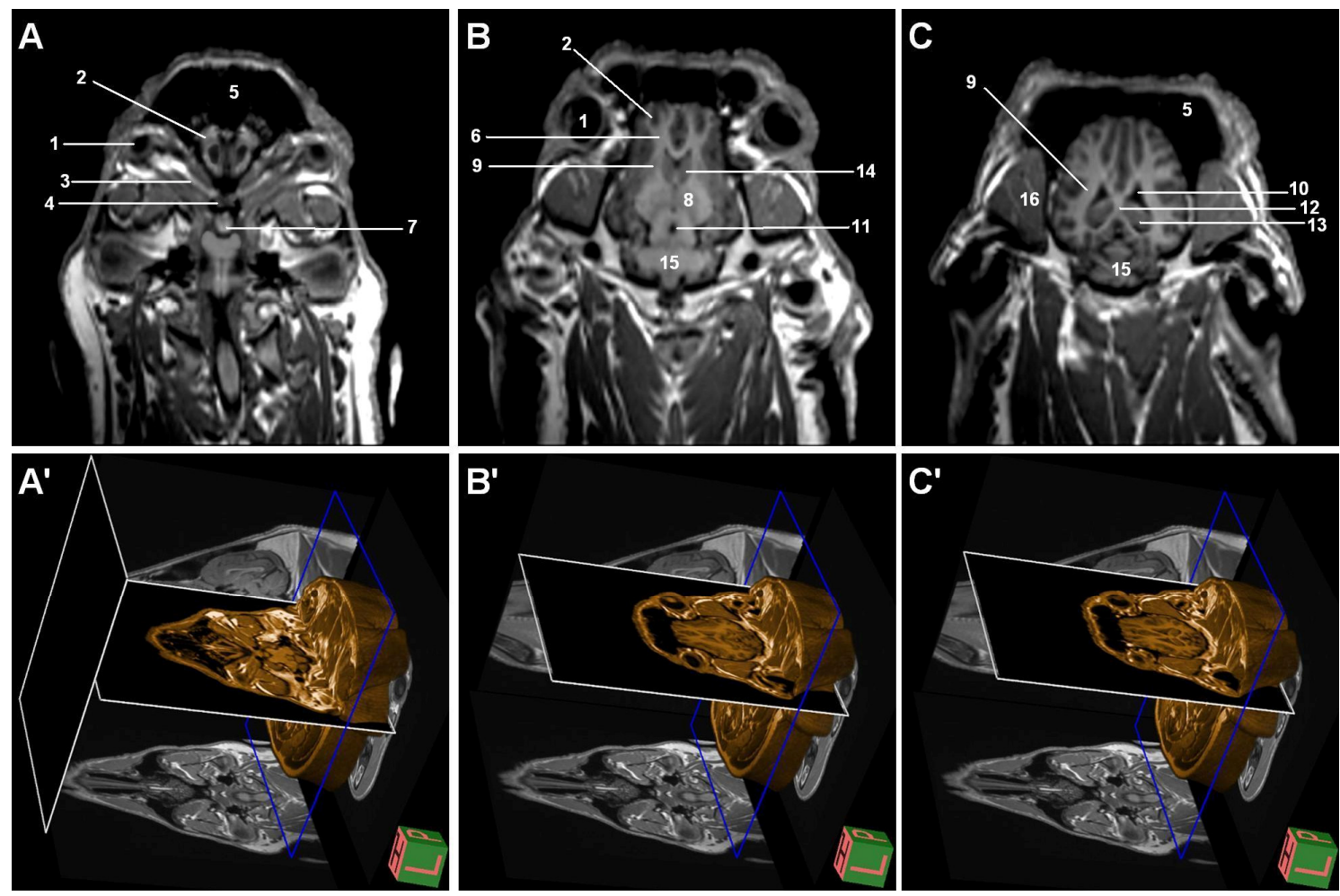

Figure 6. MR images of the brain at three levels in frontal plane. A-) T1W, B-) T1W, 3D-IR-MPR volumetric images. 1; bulbus oculi; 2; bulbus olfactorius, 3 ; n. opticus, 4 ; chiasma opticum, 5 ; sinus frontalis, 6 ; tractus olfactorius, 7; hypophysis, 8; thalamus, 9; capsula interna, 10; ventriculus lateralis, 11; aqueductus mesencephali, 12; fornix, 13; hippocampus, 14; nucleus caudatus, 15; cerebellum, 16; mm. bulbi.

Şekil 6. Frontal düzlemde, üç düzeyde, beynin MR görüntüleri, A-) T1-ağırlıkl1, B-) T1-ağırlıklı, 3D-IR-MPR volumetrik görüntüler.

neurocranium (fig 1), masticatory muscles (fig 3), salivary glands (fig 4) and the eyeballs (fig 6) were slightly hypointense, on the contrary medullary part of the bones and widely located adipose tissue on the swine body were hyperintense owing to the high signal intensity (fig 1).

After the colored reformation of images in T1W series scanned with 3D-IR-MPR sequence, the anatomic details were clearly determined in terms of the orientation and the grey and white matter were more easily distinguished from each other with high resolution (fig 1-C, 2-C, 3-C, 4-C, 5-A', B', C', 6-A', B', C').

In $\mathrm{T} 2 \mathrm{~W}$ images, the tissue contrast differences were clearly detected. Similar to T1W scans, the brain tissue was slightly hypointense. However, the white matter was more hyperintense compared with the grey matter. It was observed that the cerebrospinal fluid had a clear hyperintense signal, fat tissue was slightly hyperintense, salivary glands were isointense, muscles were slightly hypointense and the air was hypointense in all images (fig 1-B, 2-B, 3-B, 4-B).

\section{Discussion and Conclusion}

Arencibia et al. (2001) and Vasquez et al. (2001) indicated that $\mathrm{T} 1 \mathrm{~W}$ images were superior for determination of the anatomical details. On the other hand, tissue contrast differences were more clear in $\mathrm{T} 2 \mathrm{~W}$ scans. They also preferred transversal sections for demonstration of the inner brain structures. Parallel to those researches, transversal images at $\mathrm{T} 1 \mathrm{~W}$ scans seemed to be more convenient for the anatomic comprehension of the brain imaging in our study.

By means of T1W images scanned with 3D-IRMPR sequence, we reconstructed the images taken only in sagittal plane without any additional acqusition in our study. This sequence could provide us to obtain T1W images in shorter times and for all planes. We could easily distinguish grey and white matter from each other by the virtue of high resolution property of IR in this sequence. Although scanning in 3D-IR-MPR sequence has increasingly developed in last years in brain researches (15), a satisfactory investigation mentioning about the advantages of this progress in pig brain could not be found.

In conclusion, 3 Tesla MR devices with high resolution are efficient for both decreasing the scanning time and increasing signal-noise ratio which is one of the important parameters for high image quality. In addition to that, scanning of brain with 3D-IR-MPR sequence enables to delineate the anatomic details. Thereby this sequence seems to be quite effective to detect the subtle lesions located in grey and white matter intersection or in 
brain grooves. Data collected from MR images can also be processed digitally to create a standard stereotaxic space and pig brain atlas for anatomy education.

\section{Acknowledgement}

The Authors wish to thank Prof. Dr. Ergin ATALAR from UMRAM for his contribution during the study.

\section{References}

1. Arencibia A, Vasquez JM, Ramirez JA, Ramirez G, Vilar JM, Rivero MA, Alayon S, GIL F (2001): Magnetic resonance imaging of normal equine brain. Vet Radiol Ultrasound, 42, 405-408.

2. Assheuer J, Sager M (1997): MRI and CT Atlas of the Dog. 44-81. Blackwell Wissenschafts, Berlin.

3. Brown G (2010): Multiplanar reconstructed magnetic resonance imaging as a tool for anatomical investigation. Senior Radiographer MRI Unit, Department of Radiology Royal Adelaide Hospital, Australia. Erişim tarihi: 10.10.2010

Erişim adresi: http://www.ismrm.org/smrt/08/smrt.doc

4. Chaffin MK, Walker MA, McArthur NH, Perris EE, Matthews NS (1997): Magnetic resonance imaging of the brain of normal neonatal foals. Vet Radiol Ultrasound, $\mathbf{3 8 ,}$ 102-111.

5. Culp WC, Porter TR, Lowery J, Xie F, Roberson PK, Marky L (2004): Intracranial clot lysis with intravenous microbubbles and transcranials ultrasound in swine. Stroke 35, 2407-2411.

6. De Almeida JR, Ghotme K, Leong I, Drake J, James AL, Witterick IJ (2009): A new porcine skull base model: fibrin glue improves strength of cerebrospinal fluid leak repairs. Otolaryngol Head Necg Surg, 141, 184-189.

7. De Lahunta A (2009): Veterinary Neuroanatomy and Clinical Neurology. 3rd Ed. Philadelphia, London, Toronto, Mexico City, Sydney, Tokyo: W.B.Saunders Company.

8. Fang M, Li J, Gong X, Antonio G, Lee F, Kwong WH, Wai SM, Yew DT (2005): Myelinaiton of the pig's brain: A correlated MRI and histological study. Neurosignals, 14, 102-108.

9. International Committee on Veterinary Gross Anatomical Nomenclature (2005): Nomina Anatomica Veterinaria (N.A.V.). 5th ed., World association of Veterinary Anatomists, Hannover, Columbia, Gent, Sapporo.

10. Jarrahy R, Shahinain HK, Young J, Bercy G (1999): Endoscopic skull base surgery II: a new animal model for surgery of the posterior fossa. J Invest Surg, 12, 335-339.

11. König HE, Liebich HG, Cerveny C (2004): Veterinary Anatomy of the Domestic Mammals, Part 14, 465-536. In: HE König and HG Liebich (eds), Nervous System, Schattauer, Stuttgart.

12. Olsen AK, Watanabe $H$, Bjarkham $C$, Rodell A, Zeidler D, Blankholm AD, Cumming P, Gyldensted C (2003): Aporcine model for long term stroke studies. Proceeding Scand LAS Annu Symp. pp: 56.

13. Oto C (2010): Magnetic resonance imaging of the brain in donkey. Proceeding "The XXVIIth Congress of the European Association of the Veterinary Anatomists, 28-31 July, Paris”. Anat Histol Embryol, 39, 311
14. Oto C, Hazıroğlu RM (2011): Magnetic resonance imaging of the guttural pouch (diverticulum tubae auditivae) and its related structures in donkey (Equus asinus). Vet J Ankara Univ, 58, In press.

15. Phal PM, Usmanov A, Nesbit GM, Anderson JC, Spencer D, Wang P, Heleig JA, Roberts C, Hamilton BE (2008): Qualitative comparison of 3-T and 1,5-T MRI in the evaluation of epilepsy. Neuroradiol, 191, 890-895.

16. Popesko P (1979): Atlas of topografical anatomy of the domestic animals. Vol. 1, Head and Neck. 88-103. Ferdinand Enke Verlag, Stuttgart.

17. Rosendal F, Pedersen M, Sangill R, StodkildeJorgensen H, Nielsen MS, Bjarkam CR, Sunde N, Sorensen JC (2009): MRI protocol for in vivo visualization of the Göttingen minipig brain improves targeting in experimental functional neurosurgery. Brain Res Bull. 79, 41-45.

18. Schlegel KA, Rupprecht S, Petrovic L, Honert C, Srour S, Von Wilmowsky C, Felszegy E, Nkenke E, Lutz R (2009): Preclinical animal model for de novo bone formation in human maxillary sinus. Oral Surg Oral Med Oral Pathol Oral Radiol Endod, 108, 37-44.

19. Schmitt F, Grosu D, Mohr C, Purdy D, Salem K, Scott KT, Stoeckel B (2004): 3 Tesla MRI: successful results with higher field strengths: High field MR. Der Radiologe, 44, 31-48.

20. Shryock TR, Losonsky JM, Smith WC, Gatlin CL, Francisco CJ, Kuriashkin IV, Clarkson RB, Jordan WH (1998): Computed axial tomography of the porcine nasal cavity and a morphometric comparison of the nasal turbinates with other visualization techniques. Can J Vet Res, 62, 287-292.

21. Swindle MM (2007): Swine in the laboratory. 2nd ed. CRC Press, New York,

22. Vazquez JM, Rivero M, Gil F, Ramirez JA, Ramirez G, Vilar JM, Arencibia A (2001): Magnetic resonance imaging of two normal equine brains and their associated structures. Vet Rec, 148, 229-232.

23. Wang Y, Hosler G, Zhang T, Okada Y (2005): Effects of temporary bilateral ligation of the internal carotid arteries on the low and high frequency somatic evoked potentials in the swine. Clin Neuro Physiol, 116, 2420-2428.

24. Wang J, Tan HQ, Li MH, Sun XJ, Fu CM, Zhu YQ, Zhou B, Xu HW, Wang W, Xue B (2010): Development of a new model of transvenous thrombosis in the pig superior sagittal sinus using thrombin injection and balloon occlusion. J Neuroradiol, 37, 109-115

25. Watanabe H, Andersen F, Simonsen CZ, Evans SM, Gjedde A, Cumming P (2001): MR-based statistical atlas of the Göttingen minipig brain. Neuroimage, 14, 10891096.

26. Zapawa JE, Alcantara AL (1999): Welcome to the brain module. Wayne State University School of Medicine, USA. Erişim Tarihi: 10.10.2010 Erişim adresi: http://www.med.wayne.edu/diagradiology/anatomy_modul es/brain.html

Geliş tarihi: 20.10.2010 / Kabul tarihi: 22.11.2010
Address for correspondance
Assist. Prof. Dr. Çağdaş Oto
Ankara University, Faculty of Veterinary Medicine
Department of Anatomy - 06110, Ankara, Turkey
E-mail:coto@veterinary.ankara.edu.tr 